\title{
The formation and function of oviduct fluid
}

\author{
H. J. Leese \\ Department of Biology, University of York, York YO1 5DD, U.K.
}

Keywords: oviduct, oviduct fluid, embryo, spermatozoa

\section{Formation}

Before discussing the formation and function of oviduct fluid, it is useful to begin with some anatomical considerations.

\section{Anatomical considerations}

Gabriele Fallopius (1523-1562) is credited with the first correct anatomical description of the oviduct, which he termed the "tuba uteri" after its resemblance to a brass musical instrument. Nowadays the terms 'oviduct', 'Fallopian tube', 'uterine tube' and 'tube' tend to be used interchangeably. In this review, the term 'oviduct' will be used to refer to the mammal generally, the term 'Fallopian tube' to the human exclusively.

The oviduct is a muscular tube with a mucous lining. However, its gross anatomy differs considerably between species, notably in the degree of coiling. It is usually divided into 4 regions; the infundibulum, fringed by fimbriae and opening via the tubal ostium into the peritoneal cavity, the ampulla, the isthmus and the uterotubal junction. Some authors term the infundibulum and fimbriae the preampulla; the uterotubal junction is also known as the intramural or interstitial portion.

For most of its length, the oviduct has two muscle coats, an external longitudinal and an internal circular coat. The mucosa is thrown into folds, also known as 'rugae' or 'plicae'. The proportions of muscle and mucosa vary along the length of the oviduct. The best-characterized species in this respect are the cow and the rabbit (El-Banna \& Hafez, 1970; Leese, 1983), in both of which there is a gradual decline in the proportion of mucosa, the degree of mucosal folding, and the surface area of the lumen, and an increase in the proportion of muscle, as one proceeds from the infundibulum to the uterotubal junction.

\section{Vascular supply}

The blood supply to the oviduct is derived from branches of the ovarian and uterine arteries. The extent to which each artery supplies the oviduct varies between species and individuals. In general, a branch of the ovarian artery supplies the infundibulum, the ampulla and distal isthmus, while the proximal isthmus and uterotubal junction are served by a branch of the uterine artery. The two arterial systems anastomose. The venous drainage parallels the arterial supply so that there is the possibility that molecules may be transferred from the ovary via the ovarian vein into the ovarian artery and uterotubal artery, and hence into the oviduct. Hunter et al. (1983) have provided evidence for this system in the pig. Such a counter-current mechanism could explain the finding of higher concentrations of steroids in rabbit and monkey oviduct fluid than in plasma (Wu et al., 1977; Richardson \& Oliphant, 1981), although other explanations have been proposed (Jansen, 1984). 


\section{Lymphatic supply}

The oviduct has a rich lymphatic supply (Anderson, 1927). The lymphatics become greatly expanded at oestrus, coincident with an increase in the volume of oviduct fluid. The lymphatic system could also be involved in the local transfer of ovarian steroids, referred to above.

\section{Nervous supply}

The oviduct is served by both sympathetic and parasympathetic nerves (Black, 1974; Pauerstein, 1974). The isthmus has been considered as a noradrenergic sphincter (Brundin, 1969). Research on the nervous control of oviduct function has centred on the contractility of the muscle layers and their role in gamete and embryo transport. However, contraction of the oviduct will also serve to mix the contents of the lumen and minimize the build up of unstirred layers around the ciliated and secretory cells, ova, spermatozoa and early embryos. In the mouse, for example, in which the oviduct is thin-walled and relatively transparent, the to-and-fro movement of embryos and of eggs within the cumulus mass, may readily be observed. In addition to being involved in contractility, the nervous system could be involved in regulating oviduct fluid formation. Bishop (1956) found that pilocarpine, which prevents the destruction of the parasympathetic neurotransmitter acetylcholine, and acts as a vasodilator, increased the rate of rabbit oviduct fluid formation. Agents of the sympathetic nervous system, such as adrenaline, which act as vasoconstrictors and diminish the blood supply to the oviduct, would be expected to inhibit oviduct fluid formation. Alternatively, such agents might act directly on the oviduct to influence secretion rather than via effects on the circulation (Brunton, 1972). Fluid movement across other epithelial tissues such as the small intestine is readily influenced by the neurotransmitters noradrenaline and acetylcholine, which stimulate absorption and secretion respectively (Berridge, 1983).

\section{The cells of the epithelial lining}

The vast majority of the cells which border the lumen of the oviduct are of 2 types; ciliated and nonciliated or secretory. The fimbriae and infundibulum are richly ciliated, the proportion of ciliated cells declining and that of secretory cells increasing in the direction of the isthmus, where secretory cells become more abundant (Hafez, 1972; Leese, 1983).

The nutrients glucose, pyruvic and lactic acids appear in fluid recirculated through the rabbit ampulla in vivo at 1.8 times their rate of appearance in fluid recirculated through the lumen of the isthmus. This $1 \cdot 8: 1$ ratio in secretory activity corresponds most closely with the relative mucosal surface area of the two regions than with the proportion of the mucosal surface taken up by secretory cells (Leese, 1983). While such a correlation should be regarded as tentative, it does suggest that the concept that the secretory cells are concerned with the secretion of all the components of oviduct fluid is too simplistic, and that the epithelial lining to the oviduct should be considered in its entirety.

Nilsson \& Reinius (1969) have provided a detailed comparative account of the structure of the secretory and ciliated cells which comprise the oviduct epithelium. There is general agreement that secretory cells undergo a cycle of hypertrophy and atrophy throughout the oestrous cycle. In the rabbit oviduct, which is perhaps the best characterized in this respect, epithelium cell height and secretory activity increase during oestrogen dominance, with the release of secretory granules occurring after coitus or progesterone administration. However, there are species differences in both the timing of these changes, in the types of secretory granules and the nature of the secretory process (Greenwald, 1969; Beck \& Boots, 1974; Rüsse \& Liebich, 1979; Bareither \& Verhage, 1981; Odor et al., 1983).

There are conflicting reports on the cyclic changes in ciliated cells, with differences being reported between species, within oviducts of the same species and within oviducts from the same 
animal (Brenner, 1969; Odor et al., 1986). It is apparent, however, that cyclic changes in ciliated cells are not as extensive as those in non-ciliated cells (Verhage et al., 1979). Although ciliated cells are traditionally not thought to be involved in oviduct fluid formation, this notion may need to be revised as the mucosa as a whole is considered as a transporting epithelial tissue.

\section{Physiological considerations}

\section{General aspects of oviduct fluid secretion}

Although Woskressensky (1891) ligated the rabbit oviduct near the fimbriae and at the uterotubal junction and noticed that fluid accumulated between the ligatures, it is only in the past 30 years that oviduct secretions have been the subject of detailed investigation. This follows the demonstration by Bishop (1956) of 'active' secretion by the rabbit oviduct in vivo. Bishop ligated the uterotubal junction of intact rabbits and tied a cannula into the infundibulum. The cannula was adjusted to the vertical position to measure the head of pressure against which oviduct fluid could be secreted. Oestrous rabbits secreted $0.79 \mathrm{ml}$ fluid $/ 24 \mathrm{~h}$ at a maximum pressure of $46 \mathrm{~cm}$ water $(34 \mathrm{mmHg})$. The rate and pressure fell to $0.14 \mathrm{ml} / 24 \mathrm{~h}$ and $11.8 \mathrm{~cm}$ water after ovariectomy, but were restored to normal by oestradiol injection. Both secretory volume and pressure were reduced during pregnancy.

Bishop's work (1956) led to the development of techniques for the prolonged collection of oviduct fluid under various hormonal states (Clewe \& Mastroianni, 1960; Holmdahl \& Mastroianni, 1965; Hamner \& Fox, 1969). These methods provided sufficient material for chemical analysis and for experimental investigations involving spermatozoa and ova. Chemical analysis indicated that oviduct fluid is a complex mixture of constituents derived from the plasma plus some specific proteins formed by the oviduct epithelium. The best-characterized fluids are from the rabbit, sheep, cow, sow, mare, monkey and human.

The term 'transudation' was applied to the passage of plasma constituents across the oviduct wall into the lumen and the term 'secretion' to the formation and discharge of the oviduct-specific proteins. 'Transudation' implies the formation and passage of an ultrafiltrate of plasma. If oviduct fluid were solely an ultrafiltrate, its composition would parallel that of the plasma exactly. When it became apparent that certain components in oviduct fluid were present at different concentrations to those in plasma, the term 'transudation' became 'selective transudation'.

With the realization that the transport of molecules across all epithelial tissues, be they absorptive or secretory, is selective, the term transudation has fallen from use and is not found in modern physiology textbooks. Current thinking recognizes the bidirectional nature of molecular movements across epithelia (Fig. 1). There are fluxes of molecules from the fluid bathing the serosal surfaces to those bathing the mucosal surfaces and vice versa. The net flux gives the epithelium its characteristic physiology. Considered in this way, the mammalian oviduct, pancreas and salivary glands are fundamentally secretory; the small intestine, proximal kidney tubule and gall bladder fundamentally absorptive. The secretion of specific oviduct fluid constituents will now be discussed in the light of these considerations. It will be apparent that compared with tissues such as those mentioned above, our knowledge of the oviduct as a transporting epithelium is rudimentary.

\section{Electrolytes, oxygen and water}

Systematic studies of the ionic composition of oviduct fluid using micropuncture techniques and electron probe microanalysis were conducted by Borland et al. (1977, 1980). It was found that oviduct fluid was characterized by a potassium concentration significantly greater than and a calcium ion concentration significantly below that of plasma. The $\mathrm{pH}$ of oviduct fluid has traditionally been thought to be in the range of 7.5-8.0 due largely to its high concentration of bicarbonate ions. However, the techniques used in some reports to measure bicarbonate concentration were 


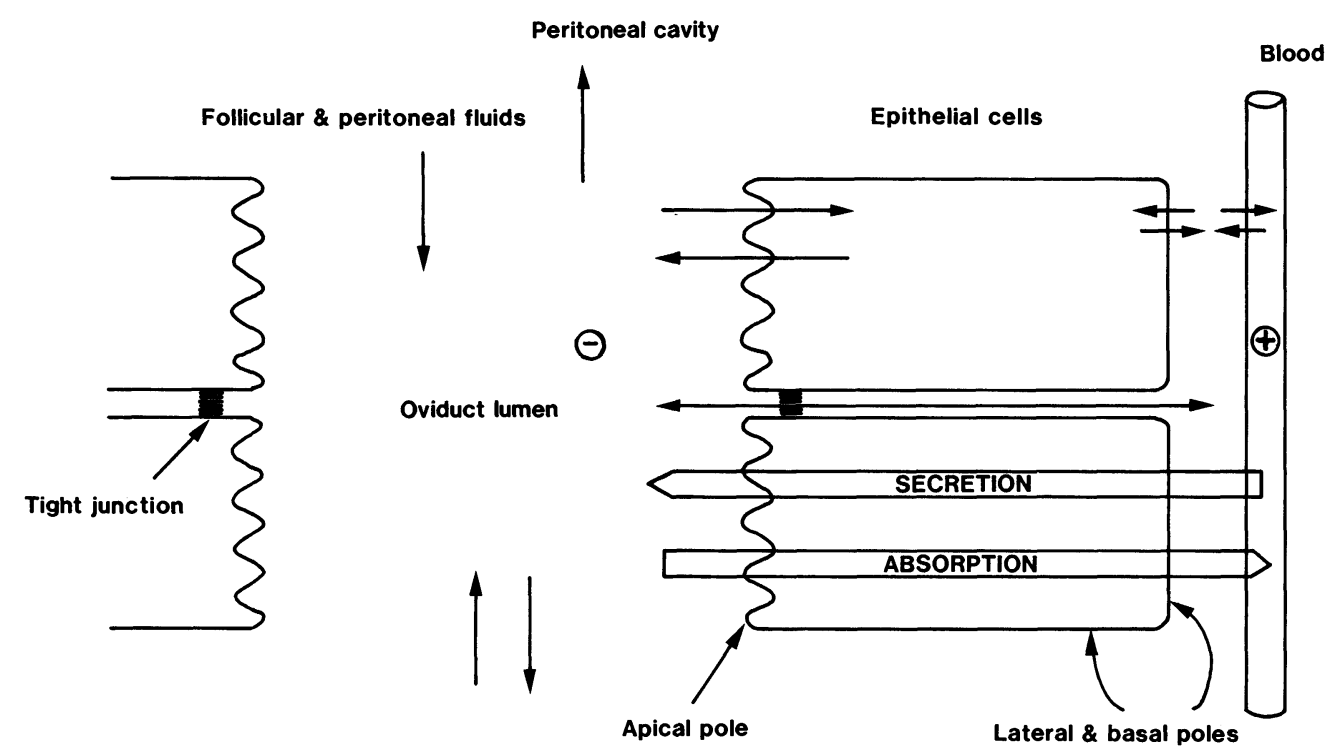

Uterine lumen

Fig. 1. Generalized diagram of the potential routes by which molecules may move into or out of the oviduct lumen.

questioned by Maas et al. (1979) who, taking care to avoid inadvertent loss of $\mathrm{CO}_{2}$ from oviduct samples collected from rhesus monkeys, found $\mathrm{pH}$ values in the range $7 \cdot 1-7 \cdot 3$ during the follicular phase with a sudden increase to 7.5-8.0 at ovulation and during the luteal phase. Bicarbonate concentrations calculated from $\mathrm{pCO}_{2}$ and $\mathrm{pH}$ measurements were $35 \mathrm{~mm}$ and $90 \mathrm{~mm}$ in the follicular and luteal phases respectively; both values were above those in the plasma.

The oxygen tension in the rabbit oviduct lumen has variously been reported to be $43 \mathrm{mmHg}$, $60 \mathrm{mmHg}$ and 21-25 mmHg (Bishop, 1965a); Mastroianni \& Jones, 1965; Ross \& Graves, 1974) with little effect of ovulation or hormonal status. By contrast, Maas et al. (1976) found very low values of $<10 \mathrm{mmHg}$ in the oviduct of the rhesus monkey during the follicular phase, with increases to approximately the same level as the blood, during and following ovulation. However, considered overall, these studies indicate that spermatozoa, ova and early embryos are exposed to an environment well able to support aerobic metabolism.

The mechanism by which ions move across the oviduct is unknown, i.e. the extent to which they move across the secretory or ciliated cells (transcellularly), or between adjacent ciliated or secretory cells (paracellularly); whether they are transported actively or passively, or in response to electrical or chemical gradients. The transmural potential difference across the oviduct in oestrous rabbits is low, at around $6 \mathrm{mV}$ (Leese \& Gray, 1985), as are the short-circuit current and tissue resistance values. These classify the tube as a so-called 'leaky epithelium' in which the bidirectional flux of ions across the tight junctions between the cells is likely to be many times greater than the net flux across the whole tissue.

The only studies to have examined ion movements across the oviduct in any detail are those of Brunton \& Brinster (1971) and Brunton (1972). Rabbit ampullae were slit open along their length and mounted as flat sheets between two bathing media. Chloride ions were shown to move actively in the direction serosa to mucosa (i.e. into the oviduct lumen in vivo) while sodium ions moved at equal rates in each direction. The secretion of chloride ions was greatly influenced by adrenergic agents such as adrenaline, noradrenaline, isoproterenol and phenylephrine. Since the blood supply 
to the preparation had been severed, these agents must have been acting on the oviduct itself, rather than the circulation.

The importance of ion movements across the oviduct lies in their coupling to the movement of water which is, of course, by far the largest component of oviduct fluid. Water is not thought to be actively transported but to move in response to osmotic gradients, largely established by the transport of ions.

To investigate the mechanism and regulation of water secretion, it is desirable to study the oviduct in isolation from the rest of the animal while maintaining it in a physiological state, to monitor the rate of fluid appearance continuously, and to be able to add compounds of interest at defined concentrations to the media bathing the tissue.

These conditions are satisfied by the technique of vascular perfusion as applied to the rabbit oviduct (Leese \& Gray, 1985). Oxygenated Medium 199 supplemented with 4\% BSA is infused into the ovarian artery at a physiological rate. A cannula of known volume is tied into the infundibulum. Oviduct fluid emerges along the cannula and its rate of production may be measured for up to $3 \mathrm{~h}$ by monitoring its progress along the tubing. The mean \pm s.e.m. rate of oviduct fluid formation in 20 oestrous does is $20.8 \pm 1.62 \mu \mathrm{l} / \mathrm{h}$. When $1 \mathrm{mM}$-cyclic AMP or a variety of agents which increase the tissue content of cyclic AMP are added to the vascular medium, oviduct fluid formation is abolished and the transmural potential difference increased from 5.5 to $8.7 \mathrm{mV}$. This latter finding is in agreement with that of Brunton (1972) who found that adrenergic agents, which would also be expected to increase the cyclic AMP content of the oviduct, increased the transmural potential difference.

Oviduct fluid formation is increased on Day 1 after mating or pseudopregnancy (A. L. Gott \& H. J. Leese, unpublished) and then declines (Oliphant et al., 1978; Spilman, 1980). It remains to be seen how far these changes and those on the control of oviduct fluid formation by cyclic AMP may be explained in terms of changes in ion fluxes, particularly of chloride ions across the tubal epithelium.

\section{Non-electrolytes}

Most of the emphasis has been on those non-electrolytes of importance to gamete and embryo metabolism, i.e. glucose, pyruvate, lactate and amino acids. Using a combined vascular and luminal perfusion system which allows the appearance of constituents in the lumen to be monitored continuously, Leese \& Gray (1985) questioned the origin of glucose, pyruvate and lactate in rabbit oviduct fluid. When glucose, pyruvate and lactate were omitted from the vascular medium, their appearance in the lumen was barely detectable, suggesting that these tubal fluid constituents were mainly derived from the blood. However, when glucose, but not lactic acid was added to the vascular compartment, lactic acid appeared in the lumen, indicating that it had been formed metabolically from glucose within the oviduct. It was estimated that, in vivo, about $75 \%$ of the lactate appearing in oviduct fluid is derived from vascular glucose and $25 \%$ from vascular lactate. A further example of the participation of the oviduct in the synthesis of oviduct fluid nutrients is the conversion of propionic acid into pyruvate, demonstrated in a luminally-perfused in-vivo preparation of the rabbit oviduct (Leese, 1980).

Table 1. Concentrations (mM) of nutrients in oviduct fluid

\begin{tabular}{|c|c|c|c|}
\hline & Glucose & Pyruvate & Lactate \\
\hline \multirow{3}{*}{$\begin{array}{l}\text { Rabbit ampulla } \\
\text { Mouse cumulus } \\
\text { Mouse distended } \\
\text { ampulla }\end{array}$} & $1.46 \pm 0.24(14)$ & $0.30 \pm 0.045(11)$ & $3.67 \pm 0.42(11)$ \\
\hline & $3 \cdot 40 \pm 0 \cdot 14(18)$ & $0.37 \pm 0.03$ & $4.79 \pm 0.32(18)$ \\
\hline & $5 \cdot 19 \pm 0 \cdot 20$ & $0.14 \pm 0.02$ & $4 \cdot 26 \pm 0 \cdot 23$ \\
\hline
\end{tabular}

Values are mean \pm s.e.m. with the number of determinations in parentheses. 
Table 1 gives the concentrations of glucose, pyruvate and lactate in neat oviduct fluid collected from the ampulla of oestrous rabbits (Leese \& Barton, 1985), from within the cumulus mass surrounding fertilized mouse oocytes and from the distended ampulla of unilaterally ovariectomized mice sampled on Day 1 after mating (D. K. Gardner \& H. J. Leese, unpublished).

The sample volumes were in the range $2 \mathrm{nl}-2 \mu \mathrm{l}$ and were obtained with the minimum of disturbance to the tubal mucosa. They were analysed by an ultramicrofluorescence technique (Leese et al., 1984; Leese \& Barton, 1984).

Two features of the data are of significance to the present discussion. Firstly, the concentrations of the nutrients in tubal fluid are all considerably below their plasma concentrations, in agreement with earlier work (Holmdahl \& Mastroianni, 1965), suggesting that their overall transport across the oviduct is by diffusion rather than active transport (Leese \& Gray, 1985). The same is true for amino acids in most species with the exception of the mare (Engle et al., 1984). Secondly, the finding that pyruvate levels in the vicinity of the cumulus mass are higher than in its absence indicates that cumulus cells can contribute to the pyruvate pool in the lumen. This was originally proposed by Biggers et al. (1967) and Donahue \& Stern (1968) and recently confirmed by Leese \& Barton (1985).

In summary, non-electrolytes in tubal fluid may (1) be transported from the blood across the oviduct unchanged, (2) synthesized in the oviduct and secreted into the lumen, (3) synthesized by cumulus cells within the lumen. There may be small contributions to tubal fluid from follicular, peritoneal and seminal fluids and by reflux of uterine fluid. However, these sources are probably minor since tubal fluid normally flows out of the oviduct, mainly into the peritoneal cavity but with a small flow through the uterotubal junction, which is increased at the time of embryo passage into the uterus (Hafez, 1963; Bellvé \& McDonald, 1968).

\section{Macromolecules}

Those derived from the blood. Although plasma proteins account for most of the protein content of oviduct fluid, their concentration is only 5-10\% of that found in serum. By far the most abundant proteins in oviduct fluid are albumin and immunoglobulin G. Oliphant et al. (1978) showed that the ability of serum proteins to enter the oviduct lumen varied inversely with their molecular size. The same authors found that the concentration of serum proteins in rabbit tubal fluid remained constant as the volume of the fluid changed during pseudopregnancy. However, Lippes et al. (1981) reported that human tubal fluid volumes and protein concentration were inversely proportional throughout the menstrual cycle. Glass (1969), using an immunocytological approach at the light microscope level with the mouse, showed that bovine serum albumin was transferred across the oviduct from the blood and entered oocytes and embryos within the lumen. The phenomenon was more apparent in the ampulla than in the isthmus. Glass (1969) felt it likely that serum macromolecules were transferred through the cells rather than between them. This was confirmed by Parr \& Parr (1986) who detected IgA and IgG in vesicles in the luminal epithelial cells of the mouse preampulla after intravenous administration. Numerous other proteins were also sequestered into vesicles and the authors considered that serum macromolecules could cross the epithelium by this route. It remains to be seen whether serum proteins are taken up into the same or separate vesicles.

Those synthesized within the oviduct. Cultured rabbit oviduct epithelium synthesizes a small number of sulphated glycoproteins identical to those found in oviduct fluid (Barr \& Oliphant, 1981; Oliphant \& Ross, 1982; Oliphant et al., 1984). The fact that they could be synthesized by isolated epithelium indicated their non-plasma origin in oviduct fluid. The results suggest that the glycoproteins were present in secretory granules within the secretory cells, that their formation was controlled by oestrogen and their release by progesterone. Hyde \& Black (1986) demonstrated a difference in the amount and type of secretion produced by the ampulla and isthmus; findings confirmed by Erickson et al. (1986). Analogous secretory glycoproteins have since been found in 
the sheep (Sutton et al., 1984), mouse (Kapur \& Johnson, 1986) and baboon (Fazleabas \& Verhage, 1986).

\section{Functional aspects of the environment within the oviduct lumen}

Oviduct fluid is the environment in which ovum transport and maturation, sperm transport and maturation, fertilization and embryo transport and early development take place. That hormonemediated changes in oviduct fluid can affect these events has been known for some time (e.g. Kille \& Hamner, 1973; Mastroianni \& Komins, 1975). Before discussing the role of oviduct fluid components in these processes, it is worth noting that oviduct fluid will also serve to keep the surface epithelium of the oviduct in a moist condition, irrespective of whether there are gametes or embryos within the lumen. Since the oviduct lumen is in continuity with the exterior of the animal, this low output of tubal fluid may also have a bacteriostatic function. In this connection, the IgA and IgG in the cells of the preampulla of the mouse oviduct (Parr \& Parr, 1986) could act locally against micro-organisms.

\section{Electrolytes}

Electrolytes will primarily be responsible for maintaining the osmolarity and $\mathrm{pH}$ of tubal fluid, but some anions and cations may have specific functions. The fact that the preimplantation embryo spends its first 3 days in a high potassium, high bicarbonate environment has often been commented upon.

Roblero \& Riffo (1986) found that a $\mathrm{K}^{+}$concentration comparable to that in oviduct fluid (25 mM) gave the highest rate of development of 2-cell mouse embryos into blastocysts, and of implantation after embryo transfer. Quinn et al. (1985) claimed that the superiority of a medium based on human tubal fluid over a modified Tyrode medium in promoting the development of mouse zygotes to blastocysts, and in improving the success of human in-vitro fertilization and embryo transfer was also due to its higher potassium ion content. However, Cummins et al. (1986) failed to confirm the findings with regard to human in-vitro fertilization.

Burkman et al. (1984) felt that the high potassium ion concentration of oviduct fluid could be involved in the inhibition of sperm motility in the lower isthmus of the rabbit (see below), an inhibition requiring pyruvate for its relief and the generation of hyperactivated sperm movement. A possible mechanism for these effects is suggested by the data of Murdoch \& White (1971) who found that increasing concentrations of $\mathrm{K}^{+}$depressed oxygen consumption and glycolysis by ram spermatozoa.

Bicarbonate at concentrations found in tubal fluid promotes the dispersal of the coronal cells surrounding the rabbit ovum (Stambaugh et al., 1969). It also stimulates sperm respiration (Hamner \& Williams, 1964).

Van Winkle et al. (1985) considered that the small difference in $\mathrm{Na}^{+}$concentration in the ampulla compared to the isthmus of the mouse oviduct was sufficient to influence the uptake of amino acids by early mouse embryos.

\section{Non-electrolytes}

Role in supporting sperm survival. Glucose, lactate and pyruvate are good exogenous substrates for spermatozoa as are other components of oviduct fluid such as amino acids and phospholipids. There is a vast literature on the utilization of substrates by spermatozoa from a wide variety of species, on the metabolic changes which occur with capacitation, and on the stimulatory or inhibitory effects of female reproductive tract fluids on sperm respiration.

The problem, as pointed out by Boell (1985) is that there has been no direct demonstration of substrate utilization by spermatozoa within the oviduct. Sperm physiology and biochemistry in 
vitro may well differ from that in vivo (Overstreet et al., 1980). It is worth digressing at this point to consider the state of spermatozoa within the oviduct.

Spermatozoa are temporarily arrested in the lower part of the isthmus in a so-called 'sperm reservoir' until shortly before ovulation. Sperm arrest may be caused to some extent in the rabbit by the presence of a tenacious mucus in the isthmus at the time of oestrus (Patek, 1974; Jansen, 1978), as well as by the high potassium environment referred to above. Arrested spermatozoa are thought to be relatively quiescent; for example, rabbit sperm motility within secretions flushed from the isthmus is reduced (Overstreet et al., 1980). The spermatozoa then migrate to the site of fertilization at or above the ampullary-isthmic junction, in a hyperactive or whiplash condition. Sperm reservoirs have been characterized for the rabbit, sheep, pig and cow and may be controlled by the ovary, through local transfer of follicular hormones, as described earlier (Hunter \& Wilmut, 1982/1983; Hunter et al., 1982; Hunter, 1984). The mean number of viable spermatozoa in the isthmus is of the order of a few thousand and, at the site of fertilization, a few tens per oocyte (Overstreet \& Cooper, 1975; Hunter, 1980; Hunter \& Nichol, 1983). These values raise interesting questions about the role of the oviduct epithelium and of tubal fluid in sperm survival.

At such low concentrations in oviduct fluid, spermatozoa will not have to compete with one another for nutrients and oxygen as they would when present as a dense suspension. Theoretical calculations show that a single spermatozoon suspended in oviduct fluid (i.e. in an essentially infinite volume) at a physiological oxygen concentration, can satisfy its oxygen requirements whilst remaining stationary (A. Hall, H. J. Leese \& D. C. S. White, unpublished). As the concentration of spermatozoa is increased, motility becomes necessary to avoid competition for the available oxygen and the build-up of an excessive 'unstirred layer' around each spermatozoon, which would eventually lead to a reduction in $\mathrm{ZO}_{2}$.

Experimental evidence that spermatozoa can remain immotile but viable comes from the work of Deutch et al. (1985) on human spermatozoa and Cardullo \& Cone (1986) on rat spermatozoa flushed from the cauda epididymidis. Both groups found that as the spermatozoa were progressively diluted, their oxygen uptake increased. A particular virtue of the experimental system used by Cardullo \& Cone (1986) was that it dispensed with the need to stir the medium in which the spermatozoa were suspended. This overcame the problem of sperm fragility which even with moderate stirring can lead to death, and enabled the respiration of spermatozoa immobilized by methyl cellulose or by immobilin to be examined. It was found that the oxygen consumption of immobilized spermatozoa did not differ from that of vigorously motile spermatozoa, lending further support to the idea that partial or complete immobilization within the oviduct does not impair sperm metabolism. The advantage to the spermatozoa of remaining in this metabolically quiescent state may be to conserve their fertilizing ability until the time of ovulation (Hunter, 1984).

However, the situation is further complicated by the question of whether spermatozoa actually float freely within oviduct fluid. A number of reports suggest they may not. Motta \& Van Blerkom (1975) indicated "that (rabbit) spermatozoa have a curious tendency to come into close contact with ciliated cells." Overstreet \& Cooper (1979) similarly stated that the majority of spermatozoa in the rabbit oviduct "appear closely associated with ciliated cells", and Fléchon \& Hunter (1981) reported that pig spermatozoa "generally made contact with the surface of non-ciliated cells, the sperm heads were either orientated flat on top of the microvilli or their tips were between epithelial cells" and contacts were also "observed between cilia and sperm cells especially over the middle part of the isthmus ... occasionally ... the sperm head ... appeared as though encircled by the tips of the cilia." Katz \& Yanagimachi (1980) showed that "the trajectories of (hamster) spermatozoa were obviously influenced by the presence of the epithelial surfaces of the oviduct." An elegant study of Suarez (1987) confirms and extends these observations on sperm-oviduct interactions. Using microscopy and videomicrography, spermatozoa were filmed directly through the transparent wall of the mouse oviduct. The spermatozoa were mainly confined to the isthmus during the periovulatory period; very few were seen in the ampulla. In some cases, the spermatozoa in the isthmus were immotile, while some motile spermatozoa adhered by their heads to the 
epithelium, breaking away periodically, moving vigorously in the lumen and then re-attaching. Columns of immotile spermatozoa were also seen. These observations are difficult to interpret. It is as though the cells of the oviduct epithelium 'nurse' the spermatozoa in some way. A close association of the spermatozoa and the epithelial cells has been described for some bats in which sperm storage occurs (see Racey, 1979).

In summary, sperm behaviour in vivo is obviously different from that in vitro with the oviduct fluid and epithelium playing a more active role than has previously been supposed. This may be one explanation for the apparent success of gamete intra-Fallopian transfer (GIFT) procedures in which spermatozoa and ova are introduced directly into the Fallopian tube.

Role in supporting oocyte and embryo survival. The evolution of media in which to culture mammalian embryos owed a good deal to early studies on the non-electrolyte composition of oviduct fluid. The best characterized species is the mouse, in which pyruvic acid is required as an energy source to support the first cleavage division of the fertilized ovum (Biggers et al., 1967). This dependence on pyruvate extends to the oocyte (Eppig, 1976). The optimal pyruvate concentration for mouse embryo development in culture is similar to that in oviduct fluid, i.e. $0 \cdot 3-0 \cdot 4 \mathrm{mM}$.

Lactate acts synergistically with pyruvate from the 2-cell stage. The concentration of lactate used in most embryo culture media is $23.3 \mathrm{~mm}$, a value within the range which Brinster (1965) found to be optimal for the development of 2-cell mouse embryos. However, lactate concentration in mouse oviduct fluid is only $4.8 \mathrm{~mm}$ (Table 1 ).

Glucose as the sole energy substrate is unable to support mouse embryo development in culture until the 8-cell stage. Its concentration in most embryo culture media is $5.56 \mathrm{~mm}$, a value higher than that found in mouse oviduct fluid $(3.4 \mathrm{~mm}$; Table 1$)$, and considerably higher than that in rabbit tubal fluid (1.46 mM). D. K. Gardner has cultured mouse embryos from the 1-cell stage to the blastocyst in the presence of $0.37 \mathrm{~mm}$-pyruvate, $3.4 \mathrm{~mm}$-glucose and $4.8 \mathrm{~mm}$-lactate, i.e. concentrations mimicking those found in vivo, and found no significant difference in rates of development compared to culture in medium M16, which contains $0.3 \mathrm{mM}$-pyruvate, $5.56 \mathrm{~mm}$-glucose and $23.3 \mathrm{~mm}$-lactate. It would seem more reasonable to use nutrient concentrations closer to those found in vivo, particularly in the case of lactate.

Amino acids are not required for the development of 1-cell mouse embryos into blastocysts in culture, though there is a requirement for a macromolecule such as bovine serum albumin.

Although it seems highly likely that ova and embryos within the oviduct consume pyruvate, glucose and lactate as they do in vitro (Gardner \& Leese, 1986), there is no evidence, as with spermatozoa, that this is the case. It is also important to be aware of species differences in substrate utilization. Rabbit preimplantation embryos for example, have significant endogenous energy reserves and do not require an exogenous fixed nitrogen source, such as albumin or amino acids for early cleavage (Kane, 1986).

Apart from histological studies showing rat embryos in very close contact with mucosal folds in the uterotubal junction (Nilsson \& Reinius, 1969), and the obvious role of cilia in gamete transport, there is no information on possible interactions between oocytes and embryos and the ciliated and secretory cells lining the oviduct lumen.

The cumulus mass may provide a microenvironment rich in pyruvate and other nutrients (Leese \& Barton, 1985) and while it persists, is likely to exclude oocytes from potential interactions with the epithelial cells. The to-and-fro movement of embryos and of eggs in cumulus has already been referred to.

Calculations on the oxygen requirement of embryos are more complicated than those on spermatozoa since the radius of the sperm mid-piece, where the mitochondria are located is approximately $2.5 \mu \mathrm{m}$, and can be considered as a point source, whereas the mitochondria within an embryo are distributed in a sphere of radius $40-60 \mu \mathrm{m}$ depending on the species. The surface area to volume ratio is obviously considerably less than in spermatozoa, and oxygen will be consumed by the mitochondria as it diffuses to the centre of the embryo. Whether these factors lead to the generation of stagnant layers around the embryo, particularly as it becomes more metabolically 
active at compaction, is unknown. A theoretical approach similar to that applied to the ovarian follicle by Gosden \& Byatt-Smith (1986) incorporating diffusion across the endosalpinx would be required to resolve this question. It is interesting that mouse embryos begin to switch to a potentially anaerobic metabolism involving the conversion of glucose to lactic acid at around the time of compaction (D. K. Gardner \& H. J. Leese, unpublished). Perhaps this change prepares the embryo for the increasingly anoxic conditions it will experience in the uterotubal junction and in the uterus before and during implantation.

\section{Macromolecules}

Whether albumin and IgG, the most abundant proteins in oviduct fluid, have embryo-specific functions is unknown. Most embryo culture media include albumin, although Kane (1985) has painstakingly demonstrated that there is more to albumin than meets the eye, and that some samples of commercial bovine serum albumin contain a low molecular weight embryonic growth factor. Glass (1963), Schlafke \& Enders (1973) and Hastings \& Enders (1974) showed histologically that preimplantation mouse, rat and rabbit embryos took up exogenous protein. This phenomenon has been characterized in some detail by Pemble \& Kaye (1986) who found that early mouse embryos took up intact ${ }^{125}$ I-labelled BSA by a temperature-sensitive, probably endocytotic, mechanism. The BSA was degraded intracellularly and the authors considered it could contribute substantially to the embryo's pool of amino acids. Wiley \& Obasaju (1986) have shown that IgG is adsorbed by mouse oocytes and embryos.

The role of the glycoproteins secreted by the endosalpinx is unknown, but clues to their function are emerging. The most conspicuous manifestation of glycoprotein secretion is the extensive mucin coat which surrounds early rabbit embryos (Greenwald, 1969).

Kapur \& Johnson (1986) have shown in the mouse that a glycoprotein of $M_{\mathrm{r}} 215000$ secreted by the oviduct is selectively sequestered into the perivitelline space of oocytes and embryos. They speculated that the glycoprotein was involved in creating a specialized microenvironment for fertilization and early development. Analogous results on the uptake of an oviduct-derived component of the hamster zona pellucida have been reported by Leveille et al. (1987).

A further role for glycoproteins may be in the control of the maternal humoral immune system, as postulated by Oliphant et al. (1984).

\section{The co-culture of embryos and oviducts}

The development of embryos in culture is delayed compared with their development within the oviduct (Bowman \& McLaren, 1970; Harlow \& Quinn, 1982). Progress in culturing embryos throughout their preimplantation stages at physiological rates has also been hampered by speciesspecific 'blocks' to development. For example, the development of embryos from random-bred mice is arrested at the 2-cell stage in culture, those of the pig at the 4-cell stage, and those of the hamster at the 2- and 4-cell stages. These observations suggest that the oviduct contributes something which is missing in vitro.

Biggers et al. (1962) showed that mouse zygotes could develop into blastocysts at the normal invivo rate within explanted oviducts maintained as organ cultures. The blastocysts gave rise to normal offspring when transferred to a suitable recipient. Subsequently, Whittingham (1968) found that mouse zygotes would only develop in the explanted ampulla region of the oviduct. The isthmus and the horn of the uterus were unable to support development. In the light of present knowledge, this may be due to the thicker wall of the isthmus limiting the supply of oxygen and nutrients to the endosalpinx.

Ironically, the very success of in-vitro fertilization, embryo culture and transfer in a few species diverted attention from the contribution to early development provided by the milieu within the oviduct. Now, in view of the continuing difficulties in culturing the embryos of certain species, the 
various blocks to development in culture, and the low rates of success in human in-vitro fertilization procedures which to some extent are thought to be due to inadequate culture conditions, the co-culture of embryos and oviducts has re-emerged as a valuable technique after a gap of 20 years. For example, Bavister \& Minami (1986) have, for the first time, overcome the '2-cell block' in hamster zygotes by growing them in cultured mouse ampullae. Rexroad \& Powell (1986) successfully used a confluent monolayer of sheep oviduct epithelial cells on which to culture early embryos for $24 \mathrm{~h}$, and Papaioannou \& Ebert (1986) used the immature mouse oviduct as a surrogate environment for rabbit and pig embryos. Gandolfi \& Moor (1987) have shown that early embryonic development in the sheep, particularly the passage through the critical 4th cell cycle is supported by co-culture with oviduct epithelial cells.

The question arising from these studies is: what factors does the oviduct contribute that are lacking in vitro? As implied earlier in this article, there are two broad possibilities; physical and/or chemical factors.

\section{Physical factors}

Whole oviduct explants, rafts of tissue or monolayers could simply be providing an appropriate substratum to promote embryonic development. One way to test this proposition would be to culture embryos on an epithelium anatomically related to the oviduct. The best candidate is the trachea, which is lined with a ciliated, secretory epithelium containing an active chloride ion pump (Shorofsky et al., 1982). Trachea explants also synthesize and secrete mucin glycoproteins which play a fundamental role in the maintenance of the sterility of the epithelial surface (Lloyd et al., 1984).

\section{Chemical factors}

The milieu occupying the lumen of the oviduct is complex and it would be unwise to assume that any of its components are redundant. However, the molecules which most obviously seem to fill the role of 'missing factors' in vitro are the oviduct-derived glycoproteins.

\section{Gamete intra-Fallopian Transfer (GIFT)}

GIFT involves the induction of follicular development oocyte aspiration, sperm collection and the placing of both gametes into the ampullar region of the oviduct. In other words, GIFT represents a more physiological approach to infertility than in-vitro fertilization for those women in which there is at least one patent Fallopian tube (Asch et al., 1985). In view of the many points of difference between the milieu of the oviduct lumen and of the medium in a culture dish, there should be no surprise that the early results with the GIFT technique are encouraging, with higher pregnancy rates than with conventional in-vitro fertilization procedures (Molloy et al., 1987).

The author's studies reported in this paper were supported by The Medical Research Council and The Wellcome Trust. I thank Ron Hunter for constructive criticism of the manuscript.

\section{References}

Anderson, D.H. (1927) Lymphatics of the Fallopian tube of the sow. Contrib. Embryol. Carnegie Instn 19, 135147.

Asch, R.H., Balmaceda, J.P., Ellsworth, L.R. \& Wong, P.C. (1985) Gamete Intra-Fallopian Transfer (GIFT): A new treatment for infertility. Int. J. Fertil. 30, $41-45$.
Bareither, M.C. \& Verhage, H.G. (1981) Control of the secretory cell cycle in cat oviduct by estradiol and progesterone. Am. J. Anat. 162, 107-118.

Barr, S.H. \& Oliphant, G. (1981) Sulfate incorporation into macromolecules produced by cultured oviductal epithelium. Biol. Reprod. 24, 852-858.

Bavister, B.D. \& Minami, N. (1986) Use of cultured 
mouse oviducts to by-pass in vitro development block in cleavage stage hamster embryos. Biol. Reprod. 34, Suppl. 1, 191, Abstr. 284.

Beck, L.R. \& Boots, L.R. (1974) The comparative anatomy, histology and morphology of the mammalian oviduct. In The Oviduct and its Functions, pp. 1-51. Eds A. D. Johnson \& C. W. Foley. Academic Press, New York.

Bellvé, A.R. \& McDonald, M.F. (1968) Directional flow of Fallopian tube secretion in the Romney ewe. $J$. Reprod. Fert. 15, 357-364.

Berridge, M.J. (1983) A general survey of the mechanism and control of intestinal fluid transport. Scand. J. Gastroenterol. 18, 43-49.

Biggers, J.D., Gwatkin, R.B.L. \& Brinster, R.L. (1962) Development of mouse embryos in organ cultures of fallopian tubes on a chemically defined medium. Nature, Lond. 194, 747-749.

Biggers, J.D., Whittingham, D.G. \& Donahue, R.P. (1967) The pattern of energy metabolism in the mouse oocyte and zygote. Proc. natn. Acad. Sci. U.S.A. 58, 560-567.

Bishop, D.W. (1956) Active secretion in the rabbit oviduct. Am. J. Physiol. 187, 347-352.

Bishop, D.W. (1956a) Oxygen concentration in the rabbit genital tract. Proc. 3rd Int. Congr. Anim. Reprod. \& A.I., Cambridge, 1, 53, Abstr.

Black, D.L. (1974) Neural control of oviduct musculature. In The Oviduct and its Functions, pp. 65-118. Eds A. D. Johnson \& C. W. Foley. Academic Press, New York.

Boell, E.J. (1985) Oxygen consumption of mouse sperm and its relationship to capacitation. J. exp. Zool. 234, 105-116.

Borland, R.M., Hazra, S., Biggers, J.D. \& Lechene, C.P. (1977) The elemental composition of the environments of the gametes and preimplantation embryo during the initiation of pregnancy. Biol. Reprod. 16, 147-157.

Borland, R.M., Biggers, J.D., Lechene, C.P. \& Taymor, M.L. (1980) Elemental composition of fluid in the human Fallopian tube. J. Reprod. Fert. 58, 479-482.

Bowman, P. \& McLaren, A. (1970) Cleavage rate of mouse embryos in vivo and in vitro. J. Embryol. exp. Morph. 24, 203-207.

Brenner, R.M. (1969) Removal of oviduct cilia during the menstrual cycle of the rhesus monkey. Fert. Steril. 20, $559-611$.

Brinster, R.L. (1965) Studies on the development of mouse embryos in vitro. IV Interaction of energy sources. J. Reprod. Fert. 10, 227-240.

Brundin, J. (1969) Pharmacology of the oviduct. In The Mammalian Oviduct, pp. 251-269. Eds E. S. E. Hafez \& R. J. Blandau. University of Chicago Press.

Brunton, W.J. (1972) Beta-adrenergic stimulation of transmembrane potential and short circuit current of isolated oviduct. Nature, New Biol. 236, 12-14.

Brunton, W.J. \& Brinster, R.L. (1971) Active chloride transport in the isolated rabbit oviduct. $\mathrm{Am}$. J. Physiol. 221, 658-661.

Burkman, L.J., Overstreet, J.W. \& Katz, D.F. (1984) A possible role for potassium and pyruvate in the modulation of sperm motility in the rabbit oviducal isthmus. J. Reprod. Fert. 71, 367-376.
Cardullo, A.A. \& Cone, R.A. (1986) Mechanical immobilization of rat sperm does not change their oxygen consumption rate. Biol. Reprod. 34, 820-830.

Clewe, T.H. \& Mastroianni, L., Jr. (1960) A method for continuous volumetric collection of oviduct secretions. J. Reprod. Fert. 1, 146-150.

Cummins, J.M., Breen, T.M., Fuller, S.M., Harrison, K.L., Wilson, L.M., Hennessey, J.F., Shaw, J.M. \& Shaw, G. (1986) Comparison of two media in a human in vitro fertilization program: lack of significant differences in pregnancy rate. Journal of In Vitro Fertilization and Embryo Transfer 3, 326-330.

Deutch, D.S., Katz, D.F. \& Overstreet, J.W. (1985) Increases in human sperm oxygen consumption at low cell concentrations. Biol. Reprod. 32, 865-871.

Donahue, R.P. \& Stern, S. (1968) Follicular cell support of oocyte maturation: production of pyruvate in vitro. J. Reprod. Fert. 17, 395-398.

El-Banna, A.A. \& Hafez, E.S.E. (1970) Profile analysis of the oviductal wall in rabbits and cattle. Anat. Res. 166, 469-478.

Engle, C.C., Foley, C.W., Plotka, E.D. \& Witherspoon, D.M. (1984) Free amino acids and protein concentrations in reproductive tract fluids of the mare. Theriogenology 21, 919-930.

Eppig, J.J. (1976) Analysis of mouse oogenesis in vitro. Oocyte isolation and the utilization of exogenous energy sources by growing oocytes. J. exp. Zool. 198, 375-382.

Erickson, M., Ross, P. \& Oliphant, G. (1986) Competition ELISA quantitation of specific sulfated oviduct glycoproteins secreted from oviduct explants. Biol. Reprod. 34, Suppl. 1, 74, Abstr. 49.

Fazleabas, A.T. \& Verhage, H.G. (1986) The detection of oviduct-specific proteins in the baboon (Papio anubis). Biol. Reprod. 35, 455-462.

Fléchon, J-E. \& Hunter, R.H.F. (1981) Distribution of spermatozoa in the utero-tubal junction and isthmus of pigs and their relationship with the luminal epithelium after mating: a scanning electron microscope study. Tissue \& Cell 13, 127-139.

Gandolfi, F. \& Moor, R.M. (1987) Stimulation of early embryonic development in the sheep by co-culture with oviduct epithelial cells. J. Reprod. Fert. 81, 23-28.

Gardner, D.K. \& Leese, H.J. (1986) Non-invasive measurement of nutrient uptake by single cultured pre-implantation mouse embryos. Hum. Reprod. 1, 25-27.

Glass, L.E. (1963) Transfer of native and foreign serum antigens to oviducal mouse eggs. Am. Zool. 3, 135-156.

Glass, L.E. (1969) Immunocytological studies of the mouse oviduct. In The Mammalian Oviduct, pp. 459 476. Eds E. S. E. Hafez \& R. J. Blandau. University of Chicago Press.

Gosden, R.G. \& Byatt-Smith, J.G. (1986) Oxygen concentration gradient across the ovarian follicular epithelium: model, predictions and implications. Hum. Reprod. 1, 65-68.

Greenwald, G.S. (1969) Endocrinology of oviductal secretions. In The Mammalian Oviduct, pp. 183-201. Eds E. S. E. Hafez \& R. J. Blandau. University of Chicago Press. 
Hafez, E.S.E. (1963) The uterotubal junction and the luminal fluid of the uterine tube in the rabbit. Anat. Rec. 145, 7-12.

Hafez, E.S.E. (1972) Scanning electron microscopy of female reproductive tract. J. Reprod. Med. 9, $119-123$.

Hamner, C.E. \& Fox, S.B. (1969) Biochemistry of Oviductal Secretions. In The Mammalian Oviduct, pp. 333-355. Eds E. S. E. Hafez \& R. J. Blandau. University of Chicago Press.

Hamner, C.E. \& Williams, W. (1964) Identification of sperm stimulating factor of rabbit oviduct fluid. Proc. Soc. exp. Biol. Med. 117, 240-243.

Harlow, G.M. \& Quinn, P. (1982) Development of preimplantation mouse embryos in vivo and in vitro. Aust. J. biol. Sci. 35, 187-193.

Hastings, R. \& Enders, A. (1974) Uptake of exogenous protein by the preimplantation rabbit embryo. Anat. Res. 179, 311-330.

Holmdahl, T.H. \& Mastroianni, L., Jr (1965) Continuous collection of rabbit oviduct secretions at low temperature. Fert. Steril. 16, 587-595.

Hunter, R.H.F. (1980) Mating, sperm transport in the female genital tract, and artificial insemination. In Physiology and Technology of Reproduction in Female Domestic Animals, pp. 104-144. Academic Press, London.

Hunter, R.H.F. (1984) Pre-ovulatory arrest and preovulatory redistribution of competent spermatozoa in the isthmus of the pig oviduct. J. Reprod. Fert. 72, 203-211.

Hunter, R.H.F. \& Nichol, R. (1983) Transport of spermatozoa in the sheep oviduct: preovulatory sequestering of cells in the caudal isthmus. J. exp. Zool. 228, 121-128.

Hunter, R.H.F. \& Wilmut, I. (1982/1983) The rate of functional sperm transport into the oviducts of mated cows. Anim. Reprod. Sci. 5, 167-173.

Hunter, R.H.F., Barwise, L. \& King, R. (1982) Sperm transport, storage and release in the sheep oviduct in relation to the time of ovulation. Br. vet. $J .138$, 225-272.

Hunter, R.H.F., Cook, B. \& Poyser, N.L. (1983) Regulation of oviduct function in pigs by local transfer of ovarian steroids and prostaglandins: a mechanism to influence sperm transport. Europ. J. Obstet. Gynec. Reprod. Biol. 14, 225-232.

Hyde, B.A. \& Black, D.L. (1986) Synthesis and secretion of sulphated glycoproteins by rabbit oviduct explants in vitro. J. Reprod. Fert. 78, 83-91.

Jansen, R.P.S. (1978) Fallopian tube isthmic mucus and ovum transport. Science, N.Y. 201, 349-351.

Jansen, R.P.S. (1984) Endocrine response in the fallopian tube. Endocrine Reviews 5, 525-551.

Kane, M.T. (1985) A low molecular weight extract of bovine serum albumin stimulates rabbit blastocyst cell division and expansion. J. Reprod. Fert. 73, $147-150$

Kane, M.T. (1986) Minimal nutrient requirements for cleavage of one-cell rabbit embryos in culture. Biol. Reprod. 34, Suppl. 1. 199, Abstr. 299.

Kapur, R.P. \& Johnson, L.V. (1986) Selective sequestration of an oviduct fluid glycoprotein in the perivitelline space of mouse oocytes and embryos. J. exp. Zool. 238, 249-260.
Katz, D.F. \& Yanagimachi, R. (1980) Movement characteristics of hamster spermatozoa within the oviduct. Biol. Reprod. 22, 759-764.

Kille, J.W. \& Hamner, C.E. (1973) The influence of oviducal fluid on the development of one-cell rabbit embryos in vitro. J. Reprod. Fert. 35, 415-423.

Leese, H.J. (1980) The stimulation of pyruvate appearance in the rabbit oviduct lumen by sodium propionate. J. Reprod. Fert. 59, 421-424.

Leese, H.J. (1983) Studies on the movement of glucose, pyruvate and lactate into the ampulla and isthmus of the rabbit oviduct. Quart. J. exp. Physiol. 68, 89-96.

Leese, H.J. \& Barton, A.M. (1984) Pyruvate and glucose uptake by mouse ova and preimplantation embryos. J. Reprod. Fert. 71, 9-13.

Leese, H.J. \& Barton, A.M. (1985) Production of pyruvate by isolated mouse cumulus cells. J. exp. Zool. 234, 231-236.

Leese, H.J. \& Gray, S.M. (1985) Vascular perfusion: a novel means of studying oviduct function. Am. J. Physiol. 248, E624-E632.

Leese, H.J., Biggers, J.D., Mroz, E.A. \& Lechene, C. (1984) Nucleotides in a single mammalian ovum or preimplantation embryo. Analyt. Biochem. 140, 443-448.

Leveille, M.C., Roberts, K.D., Chevalier, S., Chapdelaine, A. \& Bleau, G. (1987) Uptake of oviductal antigen by the hamster zona pellucida. Biol. Reprod. 36, 227-238.

Lippes, J., Krasner, J., Alfonso, L.A., Dacalos, E.D. \& Lucero, R. (1981) Human oviductal fluid proteins. Fert. Steril. 36, 623-629.

Lloyd, C., Kennedy, J.R. \& Mendicino, J. (1984) Regulation of the synthesis of mucin glycoproteins in swine trachea explants. In Vitro 20, 416-432.

Maas, D.H.A., Storey, B.T. \& Mastroianni, L., Jr (1976) Oxygen tension in the oviduct of the rhesus monkey (Macaca mulatta). Fert. Steril. 27, 1312-117.

Maas, D.H.A., Storey, B.T. \& Mastroianni, L., Jr (1979) Hydrogen ion and carbon dioxide content of the oviductal fluid of the rhesus monkey (Macaca mulatta). Fert. Steril. 28, 981-985.

Mastroianni, L., Jr \& Jones, R. (1965) Oxygen tension within the rabbit Fallopian tube. J. Reprod. Fert. 9, 99-102.

Mastroianni, L. \& Komins, J. (1975) Capacitation, ovum maturation, fertilization and preimplantation development. Gynecol. Inv. 6, 226-233.

Molloy, D., Speirs, A., du Plessis, Y., McBain, J. \& Johnston, I. (1987) A laparoscopic approach to a program of gamete intrafallopian transfer. Fert. Steril. 47, 289-294.

Motta, P. \& Van Blerkom, J. (1975) A scanning electron microscopic study of rabbit spermatozoa in the female reproductive tract following coitus. Cell Tiss. Res. 163, 29-44.

Murdoch, R.N. \& White, I.G. (1971) Studies of the stimulating effect of bicarbonate on the metabolism of ram spermatozoa. J. Reprod. Fert. 25, 231-242.

Nilsson, O. \& Reinius, S. (1969) Light and electron microscopic structure of the oviduct. In The Mammalian Oviduct, pp. 57-83. Eds E. S. E. Hafez \& R. J. Blandau. University of Chicago Press.

Odor, D.L., Gaddum-Rosse, P., Rumery, R.E. \& Blandau, R.J. (1986) Cyclic variations in the oviductal ciliated 
cells during the menstrual cycle and after estrogen treatment in the pig-tailed monkey, Macaca nemestrina. Am. J. Anat. 198, 35-57.

Odor, D., Gaddum-Rosse, P. \& Rumery, R.E. (1983) Secretory cells of the oviduct of the pig-tailed monkey, Macaca nemestrina, during the menstrual cycle and after estrogen treatment. Am. J. Anat. 166, 149-172.

Oliphant, G., Bowling, A., Eng, L.A., Keen, S. \& Randall, P.A. (1978) The permeability of the rabbit oviduct to proteins present in the serum. Biol. Reprod. 18, 516-520.

Oliphant, G., Cabot, C., Ross, P. \& Marta, J. (1984) Control of the humoral immune system within the rabbit oviduct. Biol. Reprod. 31, 205-212.

Oliphant, G. \& Ross, P.R. (1982) Demonstration of production and isolation of three sulfated glycoproteins from the rabbit oviduct. Biol. Reprod. 26, 537-544.

Overstreet, J.W. \& Cooper, G.W. (1975) Reduced sperm motility in the isthmus of the rabbit oviduct. Nature, Lond. 258, 718-719.

Overstreet, J.W. \& Cooper, G.W. (1979) The time and location of the acrosome reaction during sperm transport in the female rabbit. J. exp. Zool. 209, 97-104.

Overstreet, J.W., Katz, D.F. \& Johnson, L.L. (1980) Motility of rabbit spermatozoa in the secretions of the oviduct. Biol. Reprod. 22, 1083-1088.

Papaioannou, V.E. \& Ebert, K.M. (1986) Development of fertilized embryos transferred to oviducts of immature mice. J. Reprod. Fert. 76, 603-608.

Pauerstein, C.J. (1974) The Fallopian Tube: A Reappraisal, pp. 12-28. Lea \& Febiger, Philadelphia.

Parr, E.L. \& Parr, M.D. (1986) Uptake of immunoglobulins and other proteins from serum into epithelial cells of the mouse uterus and oviduct. J. Reprod. Immunol. 9, 339-354.

Patek, E. (1974) The epithelium of the human fallopian tube. A surface ultra-structural and cytochemical study. Acta Obstet. Scand., Suppl. 31, 1-25.

Pemble, L.B. \& Kaye, P.L. (1986) Whole protein uptake and metabolism by mouse blastocysts. J. Reprod. Fert. 78, 149-157.

Quinn, P., Kerin, J.F. \& Warnes, G.M. (1985) Improved pregnancy rate in human in vitro fertilization with the use of a medium based on the composition of human tubal fluid. Fert. Steril. 44, 493-498.

Racey, P.A. (1979) The prolonged storage and survival of spermatozoa in Chiroptera. J. Reprod. Fert. 56, $391-402$.

Rexroad, C.E. \& Powell, A.M. (1986) Co-culture of sheep ova and cells from sheep oviduct. Theriogeno$\log y$ 25, 187, Abstr.
Richardson, L.L. \& Oliphant, G. (1981) Steroid concentrations in rabbit oviduct fluid during oestrus and pseudopregnancy. J. Reprod. Fert. 62, 427-431.

Roblero, L.S. \& Riffo, M.D. (1986) High potassium concentration improves preimplantation development of mouse embryos in vitro. Fert. Steril. 45, 412-416.

Ross, R.N. \& Graves, C.N. (1974) $\mathrm{O}_{2}$ levels in the female rabbit reproductive tract. J. Anim. Sci. 39, 994, Abstr.

Rüsse, I. \& Leibich, H.G. (1979) Maturation of secretory granules in the endosalpinx one to four days post coitum in sheep. Cell Tissue Res. 201, 145-158.

Schlafke, S. \& Enders, A. (1973) Protein uptake by rat preimplantation stages. Anat. Rec. 175, 539-560.

Shorofsky, S.R., Field, M. \& Fozzard, H.A. (1982) The cellular mechanism of active chloride secretion in vertebrate epithelia: studies in intestine and trachea. Phil. Trans. R. Soc. Lond. B 299, 597-607.

Spilman, C.H. (1980) Fluid retention by the rabbit oviduct. Proc. Soc. exp. Biol. 165, 133-136.

Stambaugh, R., Noriega, C. \& Mastroianni, L., Jr (1969) Bicarbonate ions: the corona cell dispersing factor of rabbit tubal fluid. J. Reprod. Fert. 18, 51-58.

Suarez, S.S. (1987) Sperm transport and motility in the mouse oviduct: observation in situ. Biol. Reprod. 36, 203-210.

Sutton, R., Nancarrow, C.D., Wallace, A.L.C. \& Rigby, N.W. (1984) Identification of an oestrus-associated glycoprotein in oviducal fluid of the sheep. J. Reprod. Fert. 72, 415-422.

Van Winkle, L.J., Campione, A.L. \& Kester, S.E. (1985) A possible effect of the $\mathrm{Na}^{+}$concentration in oviductal fluid on amino acid uptake by cleavage-stage mouse embryos. J. exp. Zool. 235, 141-145.

Verhage, H.G., Bareither, M.L., Jaffe, R.C. \& Akbar, M. (1979) Cyclic changes in ciliation, secretion and cell height of the oviductal epithelium in women. Am. J. Anat. 156, 505-522.

Whittingham, D.G. (1968) Development of zygotes in cultured mouse oviducts. I. The effect of varying oviductal conditions. J. exp. Zool. 169, 391-398.

Wiley, L.M. \& Obasaju, M.F. (1986) Immunofluorescent localizations of immunoglobulins on the cell surface of mouse oocytes and preimplantation embryos. Journal of In Vitro Fertilization and Embryo Transfer 3, 319 .

Woskressensky, M.A. (1891) Experimentelle Untersuchungen uber die Pyo- und Hydrosalpinxbildung bei den Tieren. Zentbl. Gynaek. 15, 849-860.

Wu, C.H., Mastroianni, L., Jr \& Mikhail, G. (1977) Steroid hormones in monkey oviductal fluid. Fert. Steril. 28, 1250-1256. 